\title{
Quality of organically produced bell pepper seeds ${ }^{1}$
}

\author{
José Luiz Nogueira ${ }^{2}$, Bruna Ariane da Silva ${ }^{2}$, Átila Francisco Mógor ${ }^{3}$, \\ Camila Ribeiro de Souza Grzybowski ${ }^{*}$, Maristela Panobianco ${ }^{3}$
}

\begin{abstract}
The production of bell pepper seeds may be affected by the plant management and harvesting point of fruits. The goal of this study was to evaluate the quality of organically produced bell pepper seeds according to free plant growth, branch thinning and ripening stage. The experiment was conducted in a greenhouse with randomized block design; plants were tutored to parallel tape supports, with and without branch thinning, and fruits were harvested at three ripening stages (completely green, green/reddish and red). The following determinations were made: seed moisture content of at the time of harvest and after post-harvest rest, number of seeds per fruit, seed germination, and seedling emergence. It is possible to conclude that the production of bell pepper seeds in an organic system is viable, resulting in seeds with a germination percentage and seedling emergence above $90 \%$. The management system of plants without branch thinning results in the production of seeds with greater viability and higher quantity per fruit. The cultivation of bell peppers for seed production may be carried out with fruits at the green ripening stage (51 days after anthesis), without any quality loss.
\end{abstract}

Index terms: Capsicum annuum L., management, time of harvest, organic agriculture.

\section{Qualidade de sementes de pimentão cultivado em sistema orgânico}

\begin{abstract}
RESUMO - A produção de sementes de pimentão pode ser influenciada pelo manejo da planta e ponto de colheita dos frutos. O objetivo do trabalho foi avaliar a qualidade de sementes de pimentão produzidas em sistema orgânico, em função do crescimento livre e desbaste de ramos, e do estádio de maturação dos frutos. O experimento foi conduzido em ambiente protegido com delineamento de blocos ao acaso, sendo as plantas tutoradas com fitilhos paralelos, com e sem desbaste de ramos e frutos coletados em três estádios de maturação (completamente verde, verde/avermelhado e vermelho). As seguintes determinações foram realizadas: teor de água das sementes no momento da colheita e após repouso pós-colheita; número de sementes por fruto; germinação de sementes e emergência de plântulas. Pode-se concluir que a produção de sementes de pimentão em sistema orgânico é viável, resultando em sementes com porcentagem de germinação e emergência de plântulas superiores a $90 \%$. A forma de manejo das plantas sem o desbaste de hastes resulta na produção de sementes com maior viabilidade e quantidade por fruto. O cultivo do pimentão para a produção de sementes pode ser realizado com frutos no estádio de maturação verde (51 dias após a antese), sem prejuízo da sua qualidade.
\end{abstract}

Termos para indexação: Capsicum annuum L., manejo, ponto de colheita, agricultura orgânica.

\section{Introduction}

The bell pepper (Capsicum annum L.), a species belonging to the Solanaceae family, occupies an outstanding position among the vegetables that are commercialized in Brazil (Antoniali et al., 2012), with an annual production of approximately 290 thousand tons; the Southeastern region is

${ }^{1}$ Submitted on 01/29/2016. Accepted for publication on 04/17/2017.

${ }^{2}$ Instituto Federal Catarinense, Caixa Postal 21, 89245-000 - Araquari, SC, Brasil. the most representative one in this total (Martins et al., 2014). In the seed sector, according to the last survey performed, approximately four tons of bell pepper seeds were traded (ABCSEM, 2009).

Since the Brazilian consumer market has a demand for bell peppers the whole year (Palangana et al., 2012), this species has frequently been cultivated in a protected environment

${ }^{3}$ Departamento de Fitotecnia e Fitossanitarismo, Universidade Federal do Paraná- 80035-050 - Curitiba, PR, Brasil.

*Corresponding author <camilaribeirodesouza@gmail.com> 
(Silva et al., 2011; Palangana et al., 2012); this presents some advantages, such as better development of plants, higher productivity and fruit quality and chances of production in periods with unfavorable environmental conditions in open field (Aragão et al., 2011).

The organic cultivation of vegetables in Brazil is still performed with conventional seeds, due to the need for deep transformations in the production process in order to obtain organic seeds, and not because of the fact that there is a significant volume of companies working in this market. With the obligation of using certified organic seeds, according to the Normative Ruling n. 64 (Brasil, 2008), the Brazilian market keeps depending on import, thus increasing the production costs in the organic system (Nascimento et al., 2011).

In the attempt to promote public policies to stimulate the sector, Normative Ruling n. 46 (Brasil, 2011) defined the limit date December $19^{\text {th }}, 2013$ for the use of conventional seeds and seedlings in organic systems; however, the dead line was prorogated to 2016, since each state will have to produce annually a group of species and cultivars in which it will only be possible to use organic seeds in organic cultivations, considering the availability of the market (Brasil, 2014).

The bell pepper culture presents continuous production; it is possible to find on the same plant fruits at different ripening stages. Such inconsistency may influence the physiological quality of the produced seeds (Martins et al., 2006), since it affects the relation between assimilated compound source and their supply to the fruit/ seed, which will also be at different development stages, having needs that are typical from each phase.

On the other hand, plant management may affect the quantity and quality of the produced seeds. It is known that leaves are responsible for the production of photo-assimilated compounds and fruits for the main drains of the plant (Shirahige et al., 2010). Thus, performing the thinning of stems may reduce the source of assimilated compounds and their supply for the fruit (Duarte and Peil, 2010); consequently, this may affect developing seeds, since it reduces the availability of dry mass during the accumulation phase.

Therefore, the goal of this work was to evaluate the quality of bell pepper seeds produced in an organic system and under protected cultivation, according to stem management systems and ripening stage of fruits.

\section{Material and Methods}

Bell pepper (Capsicum annum L.) seeds from the openpollinated cultivar 'Magda' $\left(\right.$ Sakata $\left.^{\circledR}\right)$ were sown in September 2013 in expanded polystyrene trays (EPS), containing 128 cells filled with a substrate of composted pine bark mixed with composted chicken manure (Provaso ${ }^{\circledR}$ ) in the $3: 1$ proportion, kept in a protected environment with temporized irrigation. After 50 days, when the seedlings reached the height of $15 \mathrm{~cm}$ and presented five definite leaves, they were transplanted to a $14 \times 15 \mathrm{~m}$ sized arc Agricultural Greenhouse, $3.5 \mathrm{~m}$ ceiling, covered with a $150 \mu$ transparent polyethylene film, located in the organic olericulture area of the 'Centro de Estação Experimental do Canguiri' University Federal of Paraná, in the city of Pinhais, in the metropolitan region of Curitiba, with $\mathrm{Cfb}$ climate and average annual temperature of $19^{\circ} \mathrm{C}$.

The soil of the experimental area, classified as alic RedYellow Latosol with clayey texture (EMBRAPA, 2006), presented the following chemical characteristics: $\mathrm{pH}\left(\mathrm{CaCl}_{2}\right)=$ 6.6; $\mathrm{pH} \mathrm{SMP}=7.0 ; \mathrm{Al}^{+3}=0 ; \mathrm{H}+\mathrm{Al}=2.4 \mathrm{cmolc} . \mathrm{dm}^{-3} ; \mathrm{Ca}^{+2}=13.5$ cmolc. dm- ${ }^{-3} ; \mathrm{Mg}^{+2}=5.4$ cmolc. dm- ${ }^{-3} ; \mathrm{K}^{+}=1.5$ cmolc. dm ${ }^{-3} ; \mathrm{P}=$ 187.0 mg. dm ${ }^{-3} ; \mathrm{C}=27.4$ g. $\mathrm{dm}^{-3} ; \mathrm{V} \%=89$ and $\mathrm{CTC}=22.8$ cmolc. $\mathrm{dm}^{-3}$.

Two weeks after planting, the equivalent to $5.6 \mathrm{t} \mathrm{ha}^{-1}$ of organic compound was distributed on the total area (CQSFRS/SC, 2004) with average values of: $\mathrm{N}=14.3 \mathrm{~g} . \mathrm{kg}^{-1} ; \mathrm{P}=10.7 \mathrm{~g} . \mathrm{kg}^{-1} ; \mathrm{K}=11.3 \mathrm{~g}$. $\mathrm{kg}^{-1} ; \mathrm{Ca}=30.7 \mathrm{~g} \cdot \mathrm{kg}^{-1} ; \mathrm{Mg}=5.8 \mathrm{~g} . \mathrm{kg}^{-1} ; \mathrm{C}=352 \mathrm{~g}^{\mathrm{kg}} \mathrm{kg}^{-1} ; \mathrm{pH}=6.8 ; \mathrm{C} /$ $\mathrm{N}=26.6$, with later incorporation using a rotating hoe microtractor $\left(\right.$ Tobata $\left.^{\circledR}\right)$.

The transplanted seedlings were spaced $0.60 \mathrm{~m}$ between plants and $1.0 \mathrm{~m}$ between rows; the drip irrigation system was used. In order to tutor plants, plastic ribbons were placed in parallel on both sides of the plantation rows, adjacent to plants and intercropped at every $0.20 \mathrm{~m}$.

The treatments, with five replications, were distributed in randomized blocks and factor scheme composed by two stem management systems (free growth and thinning) and by three fruit ripening stages. The experiment consisted in 30 lots with seven plants each; on 15 of these lots, the thinning of stems was performed starting from the third bifurcation, leaving them with four main stems (Factor et al., 2008; Charlo et al., 2009). In all lots, under the first bifurcation, sprout thinning was performed when necessary, and flowers were removed from the first bifurcation (Blat et al., 2007). Volunteer plants control was performed by manual weeding; on the other hand, pest control, according to the organic production, occurred when needed, in accordance with Normative Ruling n. 46, issued by MAPA (Brasil, 2011).

The monitoring of fruit age, that is, the days after anthesis (DAA) was performed through marks made with tape under the insertion of each flower, in order to help harvesting. Five harvests were performed, in a 7-day interval, with the first one occurring on day 113 after seedling transplantation (DAT) and the last one on day 141. During each harvest, fruits at the three different studied development stages were collected and, at

Journal of Seed Science, v.39, n.2, p.100-105, 2017 
the end, they were grouped respecting fruit age, ripening stage and the distribution of replications on the field, thus creating the treatments to evaluate the physiological quality.

Fruits were collected at three ripening stages: completely green (51 days after anthesis - DAA), green/yellowish (60 DAA) and red (70 DAA). Fruits from each treatment remained at rest for seven days in an acclimatized room, at a temperature of $20^{\circ} \mathrm{C}$ and $70 \%$ relative air humidity.

Seed extraction was performed manually, after that, they were distributed in trays, kept in a ventilated environment at the average temperature of $22{ }^{\circ} \mathrm{C}$ and $68 \%$ relative air humidity and they were constantly turned for two days. On the third day, the seeds were submitted to drying in an oven with forced air circulation at $32{ }^{\circ} \mathrm{C}$, until reaching the moisture content of $7.0 \%$. In order to determine this content, the equation described by Cromarty et al. (1985) was used: Mf $=\mathrm{Mi}(100-\mathrm{Ui}) \times(100-$ $\mathrm{Uf})^{-1}$, where: $\mathrm{Mf}=$ sample mass after drying $(\mathrm{g}) ; \mathrm{Mi}=$ sample mass before drying $(\mathrm{g}) ; \mathrm{Ui}=$ initial moisture content $(\%)$; $\mathrm{Uf}=$ desired moisture content (\%). Later, they were stored in a twoliter airtight glass container and kept in a refrigerator at $7.5^{\circ} \mathrm{C}$ with $55.5 \%$ relative air humidity, during the analysis period in laboratory.

In the laboratory evaluations the completely randomized design was used, except for the number of seeds, which used the same design used on the field (randomized block design). The following determinations were performed:

a) Number of seeds per fruit: 10 fruits per harvest, per each treatment, were randomly sampled during the analysis period, totalizing 50 fruits per treatment, with later seed count.

b) Moisture content of recently harvested seeds: evaluated by the oven method at $105 \pm 3{ }^{\circ} \mathrm{C}$, for 24 hours, using five $3.0 \mathrm{~g}$ seed replications per treatment (Brasil, 2009). The results were expressed in average percentage per treatment, on a wet basis.

c) Seed moisture content after post-harvest rest of fruits: after the resting period of fruits (seven days), the seeds were extracted and the moisture content was determined similarly to the aforementioned.

d) Seed germination: for each treatment, 10 replications with 50 seeds were used, distributed over towel paper dampened with a water quantity equivalent to three times the mass of the dry substrate; they were kept in plastic boxes $(11.0 \times 11.0 \times 3.5 \mathrm{~cm})$ for 14 days inside a chamber with alternated temperature of $20-30{ }^{\circ} \mathrm{C}$ (Brasil, 2009). After this period, normal seedlings were counted and the results were expressed in average percentage.

e) Seedling emergence: performed with five replications of 100 seeds per treatment, distributed in 128-cell expanded polystyrene trays with composted pine bark substrate, in a greenhouse. Irrigations were daily and the total number of emerged normal seedlings was counted in each treatment after 21 days; the results were expressed in average percentage.

All collected data were submitted to statistical analysis of variance, and the averages were grouped by Tukey's test at $5 \%$ probability.

\section{Results and Discussion}

As for the number of seeds per fruit, it is possible to observe in Table 1 that there was no interaction between the two analyzed factors; there was only the effect provided by the management. Fruits coming from non-thinned plants (Table 2) presented an average seed quantity that was higher than the one from the treatment with branch thinning; thus, not performing the thinning makes the cultivation more attractive to organic seed producers, since it reduces costs and increases productivity.

Stem management may have promoted changes in the partition of photo-assimilated compounds, as well as in the redistribution of nutrients such as calcium, boron and phosphorus, which may influence the fecundation process (Marschner, 2012) and, consequently, the number of bell pepper fruit seeds; these possible changes shall be investigated in future works.

The isolated averages of the ripening stages (Table 1) did not present statistical differences, supporting what was obtained by Oliveira et al. (1999) in a work with bell peppers in conventional system.

The moisture content in recently harvested seeds (Table 1) was influenced by the interaction of the analyzed factors (Management and Ripeness). In Table 2, it is possible to observe that at the green ripening stage, seeds coming from plants with thinned branches presented a higher moisture content than the ones produced without branch thinning; it was also higher compared to seeds produced with branch thinning at the green/reddish and red ripening stages.

With the fertilization of the egg, the ripening process of seeds starts; at this point, the moisture content is high and it decreases as seeds complete their development (MarcosFilho, 2015). Oliveira et al. (1999), under conventional system, studied the physiological ripeness of bell pepper seeds according to the fruit age, observing the reduction of the moisture content of seeds along the ripening process of fruits which, on an average, reached $50.0 \%$ water when ripe.

The moisture content value of recently harvested seeds was, generally speaking, high, varying from $52.2 \%$ to $56.9 \%$ (Table 2), which may be explained by the fact that bell peppers have fleshy fruits, that during the ripening and color changing process maintain a high moisture content in their 
seeds, due to the protection provided by the pericarp (Nazário et al., 2008). After the resting period of fruits, there was no factor interaction in terms of seed moisture content (Table 1) and there was also no difference in the isolated analysis.

When analyzing the germination of organic bell pepper seeds (Table 1), it is possible to observe that there was no interaction between the factors and, in turn, plant management interfered in the viability of seeds. The quality of seeds produced with four stems per plant was lower than the one of seeds produced by non-thinned plants (Table 3), since this stem rearrangement may have modified the relation between assimilated compounds source and their supply to fruit/seeds, and there was no damage for the viability of seeds coming from green fruits, since for this variable there was no

Table 1. Analysis of variance for data about the moisture content of recently harvested seeds and after fruit resting, germination, seedling emergence and number of seeds per bell pepper fruit.

\begin{tabular}{|c|c|c|c|c|c|}
\hline Variation factor & F.D. ${ }^{(2)}$ & $\begin{array}{c}\text { M.C. }{ }^{(3)}(\%) \\
\text { Recently harvested }\end{array}$ & $\begin{array}{l}\text { M.C. }{ }^{(4)}(\%) \\
\text { rest }\end{array}$ & G. ${ }^{(5)}(\%)$ & S.E. ${ }^{(6)}(\%)$ \\
\hline Management & 1 & $3.15^{\mathrm{ns}}$ & $0.54^{\mathrm{ns}}$ & $9.47 * *$ & $0.18^{\mathrm{ns}}$ \\
\hline Ripeness & 2 & $3.01^{\mathrm{ns}}$ & $0.63^{\mathrm{ns}}$ & $0.03^{\mathrm{ns}}$ & $0.71^{\mathrm{ns}}$ \\
\hline Management x Ripeness & 2 & $4.48^{*}$ & $0.16^{\mathrm{ns}}$ & $0.78^{\mathrm{ns}}$ & $0.71^{\text {ns }}$ \\
\hline Treatments & 5 & $3.63^{*}$ & $0.42^{\mathrm{ns}}$ & $2.22^{\mathrm{ns}}$ & $0.61^{\mathrm{ns}}$ \\
\hline Waste & 24 & - & - & - & - \\
\hline Total & 29 & - & - & - & - \\
\hline C.V. (\%) & & 3.8 & 3.6 & 3.9 & 2.4 \\
\hline V.F. ${ }^{(1)}$ & F.D. ${ }^{(2)}$ & N.S & & & \\
\hline Management & 1 & & & & \\
\hline Ripeness & 2 & & & & \\
\hline Management $x$ Ripeness & 2 & & & & \\
\hline Treatments & 5 & & & & \\
\hline Blocks & 4 & & & & \\
\hline Waste & 20 & & & & \\
\hline Total & 29 & & & & \\
\hline C.V. (\%) & & & & & \\
\hline
\end{tabular}

*: significant at 5\%;**: significant at $1 \%$; ns: non-significant.

${ }^{(1)}$ Variation factor; ${ }^{(2)}$ Freedom degree; ${ }^{(3)}$ Moisture content of recently harvested seeds; ${ }^{(4)}$ Moisture content of seeds after the resting period of fruits; ${ }^{(5)}$ Germination;

${ }^{(6)}$ Seedling emergence; ${ }^{(7)}$ Number of seeds per fruit; ${ }^{(-)}$Absence of values.

Table 2. Number of seeds per fruit and moisture content of organically produced bell pepper seeds, cv. Magda, according to management system and ripening stage of fruits.

\begin{tabular}{|c|c|c|c|c|}
\hline \multirow{4}{*}{ Management } & \multicolumn{3}{|c|}{ Fruit ripening stage } & \multirow{4}{*}{ Average } \\
\hline & $\begin{array}{c}\text { Green } \\
\text { (51 DAA) }\end{array}$ & $\begin{array}{l}\text { Green/reddish } \\
\text { (60 DAA) }\end{array}$ & $\begin{array}{c}\text { Red } \\
(70 \text { DAA })\end{array}$ & \\
\hline & \multicolumn{3}{|c|}{ Number of seeds per fruit } & \\
\hline & \multicolumn{3}{|c|}{------------------------------unit------------------------- } & \\
\hline Without thinning & 200 & 269 & 262 & $244 \mathrm{a}$ \\
\hline With thinning & 206 & 147 & 220 & $191 \mathrm{~b}$ \\
\hline Average & $203 \mathrm{~A}$ & $208 \mathrm{~A}$ & $241 \mathrm{~A}$ & \\
\hline \multirow[t]{3}{*}{ C.V. (\%) } & & 25.9 & & \\
\hline & \multicolumn{3}{|c|}{ Moisture content of recently harvested seeds } & \\
\hline & \multicolumn{3}{|c|}{ 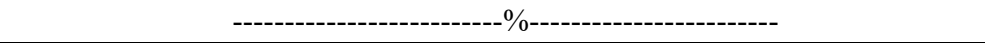 } & \\
\hline Without thinning & $52.5 \mathrm{bA}$ & $52.8 \mathrm{aA}$ & $53.9 \mathrm{aA}$ & 53.0 \\
\hline With thinning & $56.9 \mathrm{aA}$ & $52.2 \mathrm{aB}$ & $54.0 \mathrm{aB}$ & 54.3 \\
\hline Average & 54.7 & 52.5 & 54.0 & \\
\hline C.V. $(\%)$ & & 3.8 & & \\
\hline
\end{tabular}

Averages followed by the same lowercase letter in the column and the same capital letter on the line do not different among themselves by Tukey's test at $5 \%$ probability. 
Table 3. Germination and seedling emergence (vigor) of organically produced bell pepper seeds, cv. Magda, according to management system and ripening stage of fruits.

\begin{tabular}{|c|c|c|c|c|}
\hline \multirow{4}{*}{ Management } & \multicolumn{3}{|c|}{ Fruit ripening stage } & \multirow{4}{*}{ Average } \\
\hline & $\begin{array}{c}\text { Green } \\
(51 \mathrm{DAA})\end{array}$ & $\begin{array}{c}\text { Green/reddish } \\
\text { (60 DAA) }\end{array}$ & $\begin{array}{c}\text { Red } \\
(70 \text { DAA })\end{array}$ & \\
\hline & \multicolumn{3}{|c|}{ Germination } & \\
\hline & \multicolumn{3}{|c|}{ 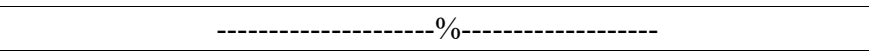 } & \\
\hline Without thinning & 98 & 95 & 96 & $96 \mathrm{a}$ \\
\hline With thinning & 91 & 93 & 92 & $92 \mathrm{~b}$ \\
\hline Average & $94 \mathrm{~A}$ & $94 \mathrm{~A}$ & $94 \mathrm{~A}$ & \\
\hline \multirow[t]{3}{*}{ C.V. $(\%)$} & & 3.9 & & \\
\hline & \multicolumn{3}{|c|}{ Seedling emergence } & \\
\hline & \multicolumn{3}{|c|}{----------------------\%\%--------------------- } & \\
\hline Without thinning & 90 & 90 & 91 & $90 \mathrm{a}$ \\
\hline With thinning & 89 & 91 & 90 & $90 \mathrm{a}$ \\
\hline Average & $90 \mathrm{~A}$ & $91 \mathrm{~A}$ & $91 \mathrm{~A}$ & \\
\hline C.V. $(\%)$ & & 2.4 & & \\
\hline
\end{tabular}

Averages followed by the same lowercase letter in the column and the same capital letter on the line do not different among themselves by Tukey's test at $5 \%$ probability.

statistical difference among the ripening stages.

It is also possible that the germination of organically produced bell pepper seeds was higher than the trading standard for the species (Brasil, 1986), that is, $70 \%$ minimum germination for distribution, transportation and commercialization of seeds and $75 \%$ for import.

The ideal period to harvest seeds is at the physiological ripeness point, characterized by the maximum accumulation of dry matter and, consequently, the best possible quality (Marcos-Filho, 2015). By the obtained data, it is possible to observe that there was no germination difference as for the ripening stage of fruits, that is, for the production of "Magda" bell pepper seeds in organic systems and protected cultivation, fruits may be harvested when green, starting from day 51 after anthesis.

Pereira et al. (2014) reported that in vegetables with fleshy fruits, seed ripeness generally coincides with the start of the color change of fruits; they however highlighted that it is not always necessary to wait for complete ripeness in order to collect them. Nonetheless, the results obtained in this research contradict literature, since maintaining fruits on the field is a decision that may reduce the physiological quality of seeds, due to the exposure to the attack of insects and pathogens.

In the analysis of seed vigor, through the seedling emergence test, there was no interaction between the factors nor isolated effect of the treatments (Table 1).This result establishes the free growth as profitable compared to branch thinning, since it provided a higher germination percentage and did not interfere in the establishment capacity of seedlings on the field. It is worth highlighting the high quality of seeds produced in an organic system and protected environment, which showed an emergence value of $90 \%$ (Table 3 ).

Under the conditions of this experiment, using the cultivar "Magda", the production of bell pepper seeds in an organic system appeared to be promising, since a high physiological potential was obtained without using agrochemicals during the development of plants. The absence of plant thinning proved to be enough for this kind of cultivation, enabling the reduction of costs and increasing the number of seeds per fruit and, also, providing higher seed viability. This management may have caused changes in the capture of photo-assimilated compounds and in the distribution of nutrients, thus affecting the fecundation process (Marschner, 2012), and increasing the production of seeds.

\section{Conclusions}

The absence of branch thinning on bell pepper plants results in the production of more viable seeds and more seeds per fruit.

The bell pepper harvest to produce seeds may be performed with fruits at the green ripening stage (51 DAA), without damages in the seed quality.

\section{Acknowledgments}

To the Coordenação de Aperfeiçoamento de Pessoal de Nível Superior - CAPES, for granting the scholarship and to Sakata Seed Sudamerica Ltda for providing the seeds. 


\section{References}

ABCSEM- Associação Brasileira do Comércio de Sementes e Mudas. 2008. Pesquisa de mercado de sementes de hortaliças. http:// www.abcsem.com.br/docs/pesquisa_mercado_2009.pdf.

ANTONIALI, S.; LEAL, P.A.M.; MAGALHÃES, A.M.; SANCHES, J. Resfriamento rápido de pimentão amarelo com ar forçado. Ciência Rural, v.42, n.6, p.1110-1116, 2012. http://www.scielo.br/pdf/cr/ v42n6/a15512cr5121.pdf

ARAGÃO, V.F.; FERNANDES, P.D.; GOMES FILHO, R.R.; NETO, A.M.S.; CARVALHO, C.M.; FEITOSA, H.O. Efeito de diferentes lâminas de irrigação e níveis de nitrogênio na fase vegetativa do pimentão em ambiente protegido. Revista Brasileira de Agricultura Irrigada, v.5, n.4, p.361- 375, 2011. http://www.inovagri.org.br/ revista/index.php/rbai/article/view/111/pdf_98

BLAT, S.F.; BRAZ, L.T.; ARRUDA, A.D.S. Avaliação de híbridos duplos de pimentão. Horticultura Brasileira, v.25, n.3, p.350354, 2007. http://www.scielo.br/pdf/hb/v25n3/a06v25n3.pdf

BRASIL. Portaria 457/1986, 18 de dezembro de 1986. Diário Oficial da União, Poder Executivo, Brasília, DF, 23 dez. 1986. Seção 1, p.19653.

BRASIL. Instrução Normativa $\mathrm{n}^{\circ}$ 64, de 18 de dezembro de 2008. Diário Oficial da União, Poder Executivo, Brasília, DF, 19 dez. 2008. Seção 1.

BRASIL. Ministério daAgricultura, PecuáriaeAbastecimento. Regras para análise de sementes. Ministério da Agricultura, Pecuária e Abastecimento. Secretaria de Defesa Agropecuária. Brasília: MAPA/ACS, 2009. 395p. http://www.agricultura.gov.br/arq_editor/ file/2946_regras_analise_sementes.pdf

BRASIL. Instrução Normativa $\mathrm{n}^{\circ}$ 46, de 06 de outubro de 2011. Diário Oficial da União, Poder Executivo, Brasília, DF, 07 out. 2011. Seção 1.

BRASIL. Instrução Normativa $\mathrm{n}^{\circ} 17$, de 18 de junho de 2014. Diário Oficial da União, Poder Executivo, Brasília, DF, 20 jun. 2014. Seção 1.

CHARLO, H.C.O.; CASTOLDI, R.; FERNANDES, C.; VARGAS, P.F.; BRAZ, L.T. Cultivo de híbridos de pimentão amarelo em fibra da casca de coco. Horticultura Brasileira, v.27, n.2, p.155-159, 2009. http://www.scielo.br/pdf/hb/v27n2/v27n2a06.pdf

CQFSRS/SC - Comissão de Química e Fertilidade do Solo. Manual de adubação e calagem para os Estados do Rio Grande do Sul e de Santa Catarina. Porto Alegre: CQFSRS/SC, 2004. 400p.

CROMARTY, A.S.; ELLIS, R.H.; ROBERTS, E.H. Design of seed storage facilities for genetic conservation. Rome: IPGRI, 1985. 100p.

DUARTE, T.D.S.; PEIL, R.M.N. Relações fonte: dreno e crescimento vegetativo do meloeiro. Horticultura Brasileira, v.28, n.3, p.271276, 2010. http://www.scielo.br/pdf/hb/v28n3/v28n3a05.pdf

EMBRAPA- Empresa Brasileira de Pesquisa Agropecuária. Centro Nacional e Pesquisa em Solos. Sistema brasileiro de classificação de solos. Brasília: Embrapa/SPI; Rio de Janeiro: Embrapa- Solos, 2006. 306p.
FACTOR, T.L.; ARAÚJO, J.A.C.; JÚNIOR, L.V.E.V. Produção de pimentão em substratos e fertirrigação com efluente de biodigestor. Revista Brasileira de Engenharia Agricola e Ambiental, v.12, n.2, 143-149, 2008. http://www.scielo.br/pdf/rbeaa/v12n2/v12n02a06.pdf

MARSCHNER, P. Marschner's mineral nutrition of higher plants. Amsterdam, Netherlands: Elsevier/Academic Press, 2012. 684p.

MARCOS-FILHO, J. Fisiologia de sementes de plantas cultivadas. 2.ed. Londrina: ABRATES, 2015. 660p.

MARTINS, G.N; SILVA, R.F.; PEREIRA, M.G.; ARAÚJO, E.F.; POSSE, S.C.P. Influência do repouso pós-colheita de frutos na qualidade fisiológica de sementes de mamão. Revista Brasileira de Sementes, v.28, n.2, p.142-146, 2006. http://www.scielo.br/pdf/rbs/ v28n2/a19v28n2.pdf

MARTINS, W.M.O.M.; FERREIRA, R.L.F.; COSTA, F.C.; ARAÚJO NETO, S.E. Compatibilidade. Agroecologia, v.9, n.1, p.205-215, 2014. http://orgprints.org/26634/1/Martins_Compatibilidade.pdf

NASCIMENTO, W.M.; VIDAL, M.C.; RESENDE, F.V. Produção de sementes de hortaliças em sistema orgânico. In: NASCIMENTO WM. (Ed.). Hortaliças: tecnologia de produção de sementes. Brasília, DF: Embrapa Hortaliças, 2011. p.61-75.

NAZÁRIO, P.; FERREIRA, S.A.N.; REBOUÇAS, E.R. Germinação de sementes de Cynometra bauhiniifolia Benthan (jutairana) em função do dessecamento e da manutenção sob condição úmida. Acta Amazônica, v.38, n.3, p.439-444, 2008. http://www.scielo.br/pdf/aa/ v38n3/v38n3a07.pdf

OLIVEIRA, A.P.; GONÇALVES, C.P.; BRUNO, R.L.A.; ALVES, E.U. Maturação fisiológica de sementes de pimentão, em função de idade de frutos após a antese. Revista Brasileira de Sementes, v.21, n.2, p.88-94, 1999. http://www.abrates.org.br/revista/artigos/1999/ v21n2/artigo15.pdf

PALANGANA, F.C.; SILVA, E.S.; GOTO, R.; ONO, E.O. Ação conjunta de citocinina, giberelina e auxina em pimentão enxertado e não enxertado sob cultivo protegido. Horticultura Brasileira, v.30, n.4, p.751-755, 2012. http://www.scielo.br/pdf/hb/v30n4/v30n4a31.pdf

PEREIRA, F.E.C.B.; TORRES, S.B; SILVA, M.I.L.; GRANGEIRO, L.C.; BENEDITO, C.P. Qualidade fisiológica de sementes de pimenta em função da idade e do tempo de repouso pós-colheita dos frutos. Revista Ciência Agronômica, v.45, n.4, p.737-744, 2014. http://www.ccarevista.ufc.br/seer/index.php/ccarevista/article/ view/2711/1027

SHIRAHIGE, F.H.; MELO, A.M.T.; PURQUERIO, L.F.V.; CARVALHO, C.R.L.; MELO, P.C.T. Produtividade e qualidade de tomates Santa Cruz e Italiano em função do raleio de frutos. Horticultura Brasileira, v.28, n.3, p.292-298, 2010. http://www. scielo.br/pdf/hb/v28n3/v28n3a09.pdf

SILVA, E.G.; TAKATA, W.H.S.; ALMEIDA, G.V.B.; EVANGELISTA, R.M.; ONO, E.O.; RODRIGUES, J.D. Qualidade de frutos de pimentão em função de concentrações de ethephon durante o amadurecimento. Revista Iberoamericana de Tecnología Postcosecha, v.12, n.2, p.199-205, 2011. http://www.redalyc.org/ pdf/813/81320900011.pdf 